\title{
Türkçe Öğretmeni Adaylarının Özdüzenlemeli Strateji Geliştirme Modeliyle Yapılandırılan Planlama ve Yazma Stratejileri Öğretimine İlişkin Görüşleri
}

\author{
Pre-Service Turkish Teachers' Opinions of Planning and Writing Strategies \\ Instruction Constructed Through Self-Regulation Strategy Development \\ Model
}

\author{
Eylem Ezgi AHISKALI ${ }^{\text {DD }}$, Dr., Balıkesir Üniversitesi Necatibey Eğitim Fakültesi, Balıkesir/TÜRKiYE, \\ eylemezgi@balikesir.edu.tr
}

Nevin AKKAYA , Doç. Dr., Dokuz Eylül Üniversitesi Buca Eğitim Fakültesi, İzmir/TÜRKiYE, nevinakkaya@deu.edu.tr

\begin{abstract}
Ahıskalı,E.E. ve Akkaya, N. (2021). Türkçe Öğretmeni Adaylarının Özdüzenlemeli Strateji Geliştirme Modeliyle Yapılandırılan Planlama ve Yazma Stratejileri Öğretimine İlişsin Görüşleri. Batı Anadolu Eğitim Bilimleri Dergisi, (2021), 12 (1), 1-17.
\end{abstract}

Öz. Bu araştırmada, özdüzenlemeli strateji geliştirme modeli ile yapılandırılan planlama ve yazma stratejileri öğretimine ilişkin Türkçe öğretmeni adaylarının görüşlerinin belirlenmesi amaçlanmıştır. Bu amaçla nitel araştırma yöntemlerinden durum çalışması kullanılmıştır. Amaçlı örnekleme yöntemi ile seçilen 24 katılımcının görüşleri yarı yapılandırılmış görüşme formu ile kaydedilmiş ve kaydedilen veriler, içerik analizi ile çözümlenerek yorumlanmıştır. Araştırmanın sonucunda çalışmaya katılan öğretmen adaylarının görüşleri, öğretimi gerçekleştirilen stratejilerin yazmaya yardımcı olduğu, yazma becerisini geliştirmeye katkı sağladığı ve tartışmacı anlatıma dayalı plan yaparken ve kompozisyon yazarken bir sav ve karşı sav oluşturmayı kolaylaştırdığı yönünde olduğu bulgulanmıştır. Ayrıca öğretmen adaylarının tamamı stratejileri öğrenirken zorluk yaşamadıklarını ve daha sonraki yazma görevlerinde bu stratejileri kullanacaklarını belirtmişlerdir. Araştırmanın sonucunda yazma becerisinin geliştirilmesinde planlama ve yazma stratejilerinin, sınıf ortamına taşınarak çeşitli uygulamalar yapılması ile anadili eğitimcisi olan Türkçe öğretmeni adaylarının yazılı anlatım becerilerini geliştirmelerine yardımcı olacağı ve gelecekte öğrencilerinin özdüzenleme becerilerini geliştiren uygun planlama ve yazma stratejilerini öğrenerek öğretmelerini sağlamada öğretmen adaylarına yararlı olacağı söylenebilir.

Anahtar Kelimeler: Özdüzenlemeli strateji geliştirme modeli, Planlama ve yazma stratejileri, Türkçe öğretmeni adayları, Görüş.

\footnotetext{
Abstract. This study aimed to identify the opinions of pre-service Turkish teachers regarding the instruction of planning and writing strategies that was constructed with self-regulation strategies development model. To serve this purpose, classified as a qualitative research method, case study was used to collect the opinions of 24 participants selected through purposeful sampling method by administering semi-structured interview forms. Subsequently, obtained opinions were analyzed with content analysis and interpreted. As the result of the study, opinions of pre-service teachers indicated that strategies that were taught helped with the writing, contributed to the development of writing skill, and facilitated the production of theses and anti-theses during planning and writing compositions based on argumentative narration. Additionally, all the pre-service teachers stated that they had no difficulties with learning the strategies and that they would use these strategies in their future writing assignments. The research concluded that planning and writing strategies would help develop written expression skills of pre-service Turkish teachers as native language educators through employing various activities in the classroom. Moreover, planning and writing strategies could enable pre-service teachers to teach suitable planning and writing strategies to their future students so as to develop their self-regulation skills.
} 
Keywords: Self-regulation strategy development, Planning and writing strategies, Pre-service Turkish teachers, Opinion. 


\section{Extended Abstract}

Introduction. Along with reading, writing skill is a skill that individuals encounter as they start their education and learning experience. They are expected to be proficient in the use of this skill acquired through education and learning for both vital matters and educational contexts. For writing skill to be acquired, writing education is included on every single level of education and teaching as an attempt to maintain the development of individuals' writing skills. The main purpose of this study is to collect the opinions of pre-service Turkish teachers regarding strategy teaching to determine the effectiveness of self-regulation strategy development model proposed by the literature to develop writing skill.

Method. In the research, case study method, which is one of the qualitative research methods, was used to reveal the effectiveness of strategy teaching constructed through self-regulation strategy development as a teaching method that can be used in various writing activities and was tested for effectiveness in many studies. Study group of the research comprised of 24 first grade university students (16 females, 8 males) who studied Turkish Language Education at a nation university in the course of 2019-2020 academic year. A "Semi-Structured Interview Form" that was tested for validity and reliability was administered to collect data. The gathered data were analyzed through content analysis and revised by the researcher and a field expert independently and asynchronously to ensure reliability.

Results, Discussion and Conclusion. Upon collective consideration of the opinions of pre-service teachers, it was evident that teaching of planning and writing strategies constructed through selfregulation strategy development directly affected writing skills in terms of aspects such as facilitating writing process by helping develop writing skill, encouraging writing in a planned and organized manner, enabling quality writing, decreasing writing anxiety and increasing willingness to write. In addition, this instruction had affective contributions to pre-service teachers such as diminishing anxiety towards writing and elevating willingness to write as well as contributions to their personal development in the sense of the ability to transfer the strategies to different tasks. On the other hand, in terms of text genre, it would make academic contributions to pre-service teachers due to implementing teaching of text genres. For a pre-service teacher to acquire the ability to teach students strategic writing and equip them with writing strategies, it necessary to develop a strategic perspective for writing. Considering that the effort of the individual is as crucial as the educator, as pre-service Turkish teachers will teach basic language skills in the first language in the future, identification of their opinions regarding planning and writing strategies will contribute to the literature. 


\section{Giriş}

Birbirini destekleyen pek çok bilgi ve becerinin bir arada kullanımını gerektiren öğretmenlik mesleği, çağın getirisi olarak yaşanan hızlı toplumsal değişimlerle birlikte çeşitli değişimlere uğramış ve günümüzde etkin öğretmenler yetiştirmeyi gerekli kılmıştır. Türkçe öğretmeni adayları özelinde düşünüldüğünde Türkçe öğretmeni adaylarının, dört temel dil becerisini öğrencilerine nasıl kazandıracaklarına ve bu beceriler aracılığıyla günümüz gereksinimlerine nasıl yanıt vereceklerine ilişkin görüşlerinin belirlenmesi alanyazına katkı sağlayacak üstünde durulması gereken bir konudur. Bu araştırmanın odağında, diğer temel dil becerilerinin gelişimine bağlı olarak daha geç gelişen ve edinimi farklı bilişsel ve üstbilişsel birçok bileşeni içeren yazma becerisi yer alır. Araştırma özdüzenlemeli strateji geliştirme modeli ile yapılandırılan planlama ve yazma stratejileri öğretimine ilişkin Türkçe öğretmeni adaylarının görüşlerinin belirlenmesi amacıyla oluşturulmuştur.

Dört temel dil becerisinin edinim sırasına göre son halkası olan yazma bir duyguyu, düşünceyi, olayı yazıyla anlatmadır (Demirel, 1999). Okul başarısı için yordayıcı bir özellik taşıyan yazma becerisi (Graham ve Perin, 2007), bireylerarası iletişimi sağlayan en önemli araçlardan biridir. Yazma iletişimsel olarak bu boyutuyla önem taşırken bilişsel olarak da düşünceleri inceleme, karşılaştırma, sorgulama işlemlerine yardım eder ve düşüncelere ilişkin düşünmenin kapısını açmaya yardımcı olur (Güneş, 2013). Düşüncelerin sınırlandırılıp sıralanarak bir düzene kavuşturulması ve ardından bu düşüncelerin yazıya dönüştürülme işinin gerçekleşmesi için yazma sürecinin amaca yönelik, stratejik, tutarlı, anlamlı olması ve dilin kurallarına uygun bir biçimde oluşturulması gerekir. Nitelikli bir yazma ürününe ulaşabilmek için yazma sırasında çeşitli aşamalardan oluşan bilişsel ve üstbilişsel birtakım işlemler uygulanır ve pek çok öğrenci nitelikli bir kompozisyonları planlama, düzenleme, değerlendirme ve yayınlama gibi yazma süreçlerinde zorlanır (Zimmerman ve Reisemberg, 1997). Bu noktada yazma stratejileri yazma sürecinde karşılaşılan bu olumsuzlukların üstesinden gelinmesine, düşüncelerin düzenlenerek yapılandırılmasına ve kâğıda aktarılmasına yardımcı olur (Mason, Harris ve Graham, 2011).

Alanyazında yazma becerisinin geliştirilmesi ve yazma sürecinde karşılaşılan zorluklara çözüm bulunabilmesi için pek çok kuram, yaklaşım ve model bulunur. Graham, Harris ve Santangelo (2015) yazmaya yönelik strateji öğretimi modellerinden özdüzenlemeli strateji geliştirme modelinin etkililiğinin diğer strateji modellerinden belirgin bir biçimde öne çıktığını belirtir. Özdüzenlemeli strateji geliştirme modeli, öğrencilerin yetkin yazarlar tarafından kullanılan planlama, yazma ve gözden geçirme stratejilerini öğrenmelerine ve düzenlemelerine yardımcı olan altı aşamalı, esnek bir öğretim modelidir (Graham ve Harris, 1999). De La Paz ve Graham'ın (1997a) özdüzenlemeli yazma stratejileri teorisi temelinde oluşturulan bu model yazma stratejilerini öğrenme ve uygulama sürecini içerir ve "1. Önbilgileri geliştirme, 2. Stratejinin amacını tartışma, 3. Stratejinin kullanımını modelleme, 4. Stratejiyi akılda tutma, 5. Stratejiyi destekleme, 6 . Bağımsız performans sergileme" olarak altı aşamadan oluşur. Uygulama sürecinde öğretimi yapılacak konu, çalışma grubunun hazırbulunuşluk düzeyi doğrultusunda uyarlanabilir. Alanyazın incelendiğinde yazmaya yönelik farklı metin türlerine uygun olarak özdüzenlemeli strateji geliştirme modeliyle yapılandırılmış çeşitli yazma stratejilerinin bulunduğu görülür. Ancak araştırmada tartışmacı anlatıma dayalı kompozisyon planlama stratejisi STOP (ASDÜYP) ve tartışmacı anlatıma dayalı kompozisyon yazma stratejisi ve DARE (GEOS) kullanılarak bu iki stratejinin öğretimine ilişkin öğretmen adaylarının görüşleri belirlemek amaçlanmıştır.

Öğrenme-öğretme sürecinin etkililiği, içeriğe uygun öğretim stratejilerinin seçimine ve bu stratejilerin etkin bir biçimde kullanılmasına bağlıdır. Bir strateji, yöntem ya da tekniğe uygun olarak yapılan öğretimsel etkinlikler hem programın verimini artırır hem de zamanın etkin kullanımını sağlayarak hedefe kolay ve başarılı olarak ulaşılmasına olanak tanır. Yetkin öğretmenler hem öğrenme görüngesini hem de öğrenme stratejilerini öğrenme süreciyle bütünleştirerek bu dengeyi sağlar 
(Pressley, Rankin ve Yokoi, 1996). Bu nedenle öğretimsel içeriklerin uygulayıcısı olan öğretmenlere, uygun strateji eğitimi vermek ve bu eğitimleri alan öğretmenlerin stratejilere yönelik görüşlerini belirlemek ve gelecek eğitimleri bu görüşler doğrultusunda planlamak oldukça önemlidir.

Günümüz öğretim anlayışında bireylerin kendi öğrenme süreçlerini oluşturması ve uygulaması, öğretmenlerin de yol gösterici rolü üstlenmesi beklenmektedir. Bu nedenle çağın öğretim anlayışına uygun olarak öğretmenlerin yazma etkinliklerinde öğrencilerini ilgili yazma hedef kazanımına yönelik stratejilere yönlendirmesi, yazma sürecinin verimini ve yazılı ürününü niteliğini artıracaktır. Özelde Türkçe öğretmeni adaylarının yazma etkinliklerinde yazma stratejilerini bilme ve uygulama becerilerinin geliştirilmesi gelecekteki öğrencilerinin yazmaya karşı olumlu bir tutum oluşturmasına ve yazma başarımlarının artmasına katkı sağlayacaktır. Yazma becerisinin geliştirilmesinde bireyin kendi çabası kadar öğreticinin de çabası önemli olduğu düşünüldüğünde bu araştırma, anadilinde temel dil becerilerinin öğretimini gerçekleştirecek olan Türkçe öğretmeni adaylarının planlama ve yazma stratejilerine ilişkin görüşlerini belirlemek açısından alanyazına katkı sağlayacaktır.

Yazma sürecinde karşılaşılan zorluklara karşı çözüm üreten araçlar olarak tanımlanabilecek yazma stratejileri, öğrencilerin yazma süreçlerinde karşılaştıkları sorunlarına etkili bir çözüm sunar. Alanyazında yazma stratejilerinin öğretimiyle ilgili metaanaliz çalışmalarında hem tek kişi hem de çok kişiyle yapılan strateji öğretiminin etki büyüklüğünün yüksek olduğu vurgulanır (Graham ve Perin, 2007; Graham, 2008; Rogers ve Graham, 2008). Alanyazın incelendiğinde özdüzenlemeli strateji geliştirme modeli kullanımı ile yazma becerisine yönelik Türkçede (Akıncılar, 2010; Can, 2016; Çağlayan Dilber, 2014; Gültekin, 2016; Müldür, 2017; Öğülmüş, 2018; Uygun, 2012) ve diğer dillerde (Balsamo, 2019; Berry ve Mason, 2012; De La Paz ve Graham, 1997a; De La Paz ve Graham, 1997b; Graham, Harris ve Mason, 2005; Harris, Graham ve Mason, 2006; Rogers, 2010; Saddler, Moran, Graham ve Harris, 2004; Zumbrun, 2010; Zumbrunn ve Bruning, 2013) çeşitli çalışmalar bulunmaktadır. Ancak özdüzenlemeli strateji geliştirme modeliyle yapılandırılan planlama ve yazma stratejileri öğretimine ilişkin Türkçe öğretmeni adaylarının görüşlerini inceleyen bir araştırmaya rastlanmamıştır. Bu nedenle araştırmada, özdüzenlemeli strateji geliştirme modeliyle gerçekleştirilen planlama ve yazma stratejileri öğretimine ilişkin Türkçe öğretmeni adaylarının görüşlerini belirlemek amaçlanmıştır. Bu amaç doğrultusunda şu sorulara yanıt aranmıştır:

1. Öğrendiğiniz planlama ve yazma stratejileri konusunda ne düşünüyorsunuz?

2. Planlama ve yazma stratejilerini kullanmak yazmaya yönelik düşüncelerinizi nasıl etkiledi?

3. Öğrendiğiniz planlama ve yazma stratejileri tartışmacı anlatıma dayalı plan yapma ve kompozisyon yazma becerinizi nasıl etkiledi?

4. Süreç boyunca öğrendiğiniz planlama ve yazma stratejileri konusunda yaşadığınız zorluklar nelerdi?

5. Öğrendiğiniz planlama ve yazma stratejilerini daha sonraki yazma görevlerinizde kullanır mısınız?

\section{Yöntem}

\section{Araştırmanın Deseni}

Araştırma, özdüzenlemeli strateji geliştirme modeliyle yapılandırılan planlama ve yazma stratejileri öğretimine ilişkin Türkçe öğretmeni adaylarının görüşlerini incelemeyi ve betimlemeyi amaçlayan nitel bir araştırmadır. Buradan hareketle, çalışmanın deseni nitel betimsel araştırma deseni olarak belirlenmiş̧ir. Betimsel (descriptive) araştırmalar, verilen bir durumu olabildiğince tam ve dikkatli bir biçimde tanımlar (Büyüköztürk, Çakmak, Akgün, Karadeniz ve Demirel, 2019). Verilerin görüşülenden elde edildiği biçimi değiştirilmeden alıntılarla aktarıldığı desen; betimsel analiz için bir 
çerçeve oluşturma, tematik çerçeveye göre verilerin işlenmesi, bulguların tanımlanması, bulguların yorumlanması olarak dört aşamadan oluşur (Altunışık, Coşkun, Bayraktaroğlu, Yıldıım, 2012). Araştırmacılar için betimsel analizin, araştırmacıların çalışmak istediği farklı olgu ve olaylara yönelik özet bilgi elde edebilmeleri için sıklıkla başvurduğu bir yöntem olduğu belirtilir (Büyüköztürk vd., 2019).

\section{Çalışma Grubu}

Araştırmanın çalışma grubunu, 2019-2020 eğitim-öğretim yılında bir devlet üniversitesinin Türkçe öğretmenliği anabilim dalında öğrenim gören 24 birinci sınıf öğrencisi (16 kadın, 8 erkek) oluşturur. Çalışma grubunun belirlenmesinde ölçüt örnekleme (criterion sampling) yöntemi kullanılmıştır. Örneklemin belirlenmesinde ölçüt, özdüzenlemeli strateji geliştirme modeliyle yapılandırılan planlama ve yazma stratejileri öğretimini almış olmaktır. Ölçüt örneklemede araştırmacı, araştırmasında gözlem birimleri belli niteliklere sahip kişiler, olaylar, nesneler ya da durumlardan oluşturulabilir. Bu durumda örneklem için belirlenen ölçütü karşılayan birimler örnekleme alınır (Büyüköztürk, vd., 2019).

\section{Veri Toplama Yöntemi ve Araçları}

Araştırmada veri toplama tekniği olarak görüşme tekniği kullanılmıştır. Görüşme tekniği soruyanıt yöntemi ile bir ilişkiyi kurma ve bir veriye ulaşma amacı ile veri toplanmasıdır (Yıldırım ve Şimşek, 2013). Görüşmeler, araştırmacı tarafından geliştirilen ve beş sorudan oluşan yarı yapılandırılmış görüşme formuyla gerçekleştirilmiştir. Bu doğrultuda ilk olarak araştırmacı tarafından dört soruluk yarı yapılandırılmış görüşme formu hazırlanmıştır. Hazırlanan görüşme soruları deney grubundaki öğretmen adaylarının planlama stratejilerine ilişkin görüşlerini, bu stratejilerin kullanmanın yazmaya yönelik düşünceleri üzerinde etkisi olup olmadığı, süreç içinde karşılaşılan zorluklar ve sonraki yazma görevlerinde kullanma durumunu belirleyecek yapıda tasarlanmıştır. Hazırlanan bu görüşme soruları ilk olarak beş Türkçe eğitimi alan uzmanı ve bir ölçme değerlendirme uzmanının görüşlerine sunulmuş ardından gelen dönütler doğrultusunda forma bir soru daha eklenmiş ve form yapılandırılarak araştırmada kullanılmak üzere beş soruluk son biçimini almıştır. Uzman görüşleri, yarı yapılandırılmış görüşme formunun geçerliliğini sağlamak için yeterli bulunmuştur.

\section{Veri Toplama Süreci}

Araştırmada, araştırmanın temel amaç ve kazanımlarına uygun haftada üç ders saati ve 10 hafta süreyle 10 ayrı etkinlik planı hazırlanmıştır. Programda uygulanan etkinlikler Tablo 1'de verilmiştir:

Tablo 1.

Etkinlik Planları

\begin{tabular}{ll}
\hline Hafta & Etkinlik \\
\hline 1.Hafta & "Başlıyoruz" \\
2.Hafta & "Sence Hangisi? " \\
3.Hafta & "Metnin Izinde 1" \\
4.Hafta & "Metnin İinde 2" \\
5.Hafta & "Model Geliyor 1" \\
6.Hafta & "Stratejiyi Tanıyorum 1" \\
7.Hafta & "Stratejiyi Tanıyorum 2" \\
8.Hafta & "Model Geliyor 2" \\
9.Hafta & "Dene Bakalım!" \\
10.Hafta & "Yazıorum! \\
\hline
\end{tabular}


Tablo 1'de görüldüğü gibi araştırmada 10 hafta süreyle 10 ayrı etkinlik gerçekleştirilmiştir. Uygulamanın son haftasında öğretimin tamamlanmasının ardından öğretmen adaylarının görüşlerini belirlemek için yarı yapılandııımış görüşme formu kullanılarak öğretmen adaylarının görüşleri alınmıştır. Dokuz Eylül Üniversitesi Enstitü Etik Kurulunun yaptığı incelemelerin ardından araştırmanın etik olarak uygunluğu 06.12.2019 tarihi, 15563195-300.99-E.101225 belge sayı numarasıyla onaylanmıştır.

\section{Verilerin Analizi ve Yorumlanması}

Araştırmada verilerin çözümlenmesinde betimsel analiz kullanılmıştır. Araştırma sonucunun araştırma soruları dikkate alınarak sunulmasına olanak veren betimsel analiz; elde edilen verilerin daha önceden belirlenen temalara göre özetlenip yorumlandığı, görüşülen bireylerin görüşlerini çarpıcı bir biçimde yansıtmak amacıyla sık sık doğrudan alıntıların kullanıldığı ve elde edilen sonuçların nedensonuç ilişkileri çerçevesinde yorumlandığı analiz tekniğidir (Yıldırım ve Şimşek, 2013). Araştırmada yarı yapılandırılmış görüşme formunda yer alan beş araştırma sorusu tema olarak ele alınmış ve her bir araştırma sorusuna verilen yanıtlara ilişkin oluşturulan kategorilere ilgili soru altında yer verilmiştir.

Nitel veri analizi süreci ham verilerden kodlara doğru işleyen tümevarımsal bir süreçtir (Cresswell, 2013). Bu nedenle araştırma sonucunda elde edilen veriler aşamalı olarak analiz edilmiş ve "analiz öncesi hazırlık, verileri eşleştirme, verileri sınıflandırma ve verilerin analizi" olarak dört aşamada (Miles ve Huberman, 1994) gerçekleşmiştir. Bu aşamalar birbirini izleyen ve etkileyen eş zamanlı akışlar bütünü olarak ele alınmıştır (Roberts ve Priest, 2006). Analiz öncesi hazırlık aşamasında, her bir görüşme formuna bir numara verilmiş ve formda yer alan yanıtlar sırayla okunmuş ve Office programına aktarılmıştır. Görüşme formunun dökümünün ardından yanıtlar tekrar okunarak yanıtların her birinde ortak olan betimlemeler işaretlenmiştir. Verileri eşleştirme aşamasında, işaretlenen betimlemeler eşleştirilerek tema olarak kabul edilen araştırma soruları altında toplanmıştır. Ayrıca öğrencilerin görüşlerinden hangi alıntıların yapılacağı belirlenerek listelenmiştir. Verileri sınıflandırma aşamasında, eşleştirilen verilerden anlamca birbirine benzer özelliği olanlar ve sıklıkla değinilen ifadeler seçilerek kodlar oluşturulmuştur. Bu kodlardan yola çıkılarak çeşitli kategoriler oluşturulmuş, oluşturulan kategoriler sınıflandırılmış ve veriler analize hazır biçime getirilmiştir. Verilerin analizi aşamasında, kategoriler ve kodlara ilişkin frekans ve yüzde değerleri hesaplanmıştır.

Analizler, güvenirliğinin sağlanabilmesi için araştırmacının kendisi ve bir alan uzmanı tarafından farklı zamanlarda yapılmıştır. Görüşme formundan ele edilen dökümler çoğaltılarak araştırmacının ve alan uzmanın ayrı ayrı değerlendirilmesi sağlanmıştır. Yapılan değerlendirmenin ardından iç tutarlılı̆ı belirlemek amacıyla her sorunun yanıtı tek tek incelenerek karşılaştırılmıştır. Ardından her iki araştırmacı önceki aşamada oluşturulan kodları her bir katılımcı için gözden geçirmiş ve kodları karşılaştırmıştır. Kodların karşılaştırılması sürecinde veri analizinin güvenirliğinin sağlanabilmesi için Miles ve Huberman'ın (1994) önermiş olduğu güvenirlik formülünden (Güvenirlik = Görüş birliği / (Görüş Birliği + Görüş Ayrılığı) x 100) yararlanılarak araştırmacılar arası uyuşum yüzdesi hesaplanmıştır. Formüle göre kodlamalardaki uyuşum yüzdesi \%0,91 olarak hesaplanmıştır. Güvenirlik hesaplamasındaki uyuşum yüzdesi \%70 olduğunda güvenirlik yüzdesine ulaşılmış kabul edilir (Yıldırım ve Şimşek, 2013). Ayrıca araştırmanın iç geçerliğini artırabilmek için oluşturulan kategorilerin analizi ile görüşme sorularına verilen yanıtlardan doğrudan alıntılar sunulmuştur. Analiz sonuçlarına ilişkin diğer bilgiler, bulgular bölümünde ayrıntılı olarak verilmiştir. 


\section{Bulgular}

\section{Öğretmen Adaylarının Planlama ve Yazma Stratejilerine İlişkin Düşüncelerine Yönelik Bulgular}

Öğretmen adaylarının özdüzenlemeli strateji geliştirme modeli ile yapılandırılan planlama ve yazma stratejileri öğretimine yönelik görüşlerini belirlemek için oluşturulmuş yarı yapılandırılmış görüşme formunda bulunan ilk soru "Öğrendiğiniz planlama ve yazma stratejileri konusunda ne düşünüyorsunuz?” sorusudur. Öğretmen adaylarının planlama ve yazma stratejilerine ilişkin görüşleri ile oluşturulan kategoriler ve her bir kategoriye ilişkin frekans ve yüzde değerleri Tablo 2'de verilmiştir.

Tablo 2.

Öğretmen adaylarının planlama ve yazma stratejilerine ilişkin görüşleri

\begin{tabular}{lrr}
\hline Kategori & \multicolumn{2}{c}{$\%$} \\
\hline Yazma becerisini geliştirmeye yardımcı olma & 11 & 46 \\
Daha nitelikli yazılar yazmayı sağlama & 9 & 38 \\
Daha kolay yazmayı sağlama & 4 & 17 \\
\hline
\end{tabular}

Tablo 2'ye göre öğretmen adaylarının planlama ve yazma stratejilerine ilişkin görüşleri incelendiğinde, en çok ( $\mathrm{f}=11$ ) "yazma becerisini geliştirmeye yardımcı olma" kategorisinde görüş bildirilmiştir. Öğretmen adaylarından (ÖA7) "Yazma becerisi üzerinde olumlu etkisi var ve çok faydalı." ve (ÖA10) "Yazma becerisine çok faydalı olduğunu düşünüyorum." ifadeleri ile stratejilerin yarar boyutundaki etkisine değinirken, (ÖA1) "Yazma konusunda kendimi geliştirdiğini düşünüyorum." ve (ÖA21) "Strateji öğrenmek yazımı geliştirdi. Daha doğru yazmak için anlamlı ve gerekli olduğunu düşünüyorum." diyerek bu stratejilerin hem bireysel gelişimlerine hem de yazma becerisindeki gelişimlerine yönelik etkisine vurgu yapmıştır.

Planlama ve yazma stratejilerine ilişkin ikinci olarak $(\mathrm{f}=8)$ "daha nitelikli yazılar yazmayı sağlama" kategorisinde görüş bildirilmiştir. Bu görüşte olan öğretmen adaylarından (ÖA13) "Bu stratejiler sayesinde daha sağlam yazılar yazıyorum.", (ÖA16) "Doğru yazmanın doğru planlama ile vazgeçilmez bir bağı var. Bu stratejilerle daha sağıklı yazdığımı düşünüyorum." ve "Daha kaliteli yazmamı ve daha fazla argüman üreterek yazmamı sağladı." (ÖA24) diyerek yazılan metnin niteliksel özelliklerine değinmiş ve stratejileri kullanmanın bu niteliği artırdığına yönelik metaforik bir ifadeler kullanmıştır. Ayrıca öğretmen adaylarından (ÖA4) "Bu stratejiler kesinlikle işe yarıyor. Yazarken konu dışına çıkmamı engelledi." görüşü ile öğrendikleri stratejilerin konu dışına çıkmayarak daha nitelikli yazılar yazmayı sağladığına değinmiştir.

Öğretmen adayları, öğrendikleri planlama ve yazma stratejilerine ilişkin üçüncü olarak ( $f=4)$ "daha kolay yazmayı sağlama" kategorisinde görüş bildirmiştir. Öğretmen adaylarından (ÖA14) "Yazmadan önce bir zihin haritası yapmak daha kolay yazmamı sağladı." diyerek yazma öncesinde kullandığı planlama stratejilerine, (ÖA15) "Güzel ve doğru yazmak için gerekli olduğunu düşünüyorum. Yazma sürecini kolaylaştırıyor." diyerek yazma stratejilerine ve (K19) "Düşüncelerimi daha kolay kâğıda dökmemi sağladı." diyerek stratejilerin bilişsel olarak yazma sürecini kolaylaştırmasına yönelik görüş bildirmiştir.

\section{Öğretmen Adaylarının Planlama ve Yazma Stratejilerinin Yazmaya Etkisine ilişskin Düşüncelerine Yönelik Bulgular}

Yarı yapılandırılmış görüşme formundaki ikinci soru "Planlama ve yazma stratejilerini kullanmak yazmaya yönelik düşüncelerinizi nasıl etkiledi?" sorusudur. Öğretmen adaylarının 
öğrendikleri planlama ve yazma stratejilerini kullanmanın onların yazmaya yönelik düşüncelerine olan etkisine ilişkin görüşleri ile oluşturulan kategoriler ve her bir kategoriye ilişkin frekans ve yüzde değerleri Tablo 3'te verilmiştir.

Tablo 3.

Öğretmen adaylarının planlama ve yazma stratejilerini kullanmanın yazmaya yönelik düşüncelerine etkisine ilişkin görüşleri

\begin{tabular}{lrr}
\hline Kategori & f & \multicolumn{2}{c}{$\%$} \\
\hline Yazmaya yardımcı olma ve yazmayı kolaylaştırma & 11 & 46 \\
Düzenli ve sitemli yazmayı sağlama & 7 & 29 \\
Yazmaya yönelik kaygıyı azaltma & 4 & 17 \\
Yazma isteğini artırma & 2 & 8 \\
\hline
\end{tabular}

Tablo 3'e göre planlama ve yazma stratejilerini kullanmanın yazmaya yönelik düşüncelerine etkisine ilişkin öğretmen adaylarının görüşleri incelendiğinde, en çok $(\mathrm{f}=11)$ "yazmaya yardımcı olma ve yazmayı kolaylaştırma"ya yönelik görüş bildirildiği görülür. Öğretmen adaylarından (ÖA11) "Yazmamı kolaylaştırdı." ya da (ÖA23) "Kompozisyonu kolayca yazmama yardımcı oldu." biçiminde görüş bildirirken (ÖA8) "Yazmanın kolay olduğunu fark etmemi sağladı." ve (ÖA5) "Nerde nasıl yazacağımı bildiğim için yazmam kolaylaştı." diyerek düşüncelerini açıklamıştır. Planlama ve yazma stratejilerinin yazmaya yönelik düşüncelerine etkisine ilişkin ikinci olarak $(\mathrm{f}=7)$ "Düzenli ve sistemli yazmayı sağlama" kategorisinde görüş bildirilmiştir. Öğretmen adaylarından (ÖA19) "Daha düzenli ve sistematik yazmamı sağladı." ve (ÖA16) "Daha sistemli yazmamı sağladı." ifadeleriyle öğrendikleri bu stratejilerin yazdıkları kompozisyonun yapısal özelliklerini düzenlediğine değinirken, (ÖA21) "Düşüncelerimi daha düzenli ve anlaşılır bir biçimde yazıya aktarmamı sağladı." ve (ÖA18) "Bir yazıya başlamadan önce o konuyla ilgili bilgi edinerek ve plan yaparak sistemli ve düzenli yazmak gerektiğini anlamamı sağladı." ifadeleriyle öğrendikleri bu stratejilerin yazdıkları kompozisyonun içeriğindeki düzenine de katkı sağladığına değinmiştir.

Planlama ve yazma stratejilerinin yazmaya yönelik düşüncelerine etkisine ilişkin üçüncü olarak $(\mathrm{f}=4)$ "Yazmaya yönelik kaygıyı azaltması"na yönelik görüş bildirilmiştir. Buna duruma uygun olarak (ÖA1) "Yazmaya yönelik korkumu azaltarak beni rahatlattı." ve (ÖA22) "Endişemi ve telaşımı azalttı." diyerek yazmaya yönelik kaygılarını azalltıklarını ifade etmişler ve dahası (ÖA10)"Artık daha iyi ve çekinmeden yazıyorum." ve (ÖA12) "Korkusuzca ve rahat yazabilmemi sağladı." gibi ifadelerle de yazmaya yönelik korku ve çekincelerini bırakıp rahat yazabilmek için de öğrendikleri stratejilerin yararlı olduğunu belirtmiştir. Planlama ve yazma stratejilerinin yazmaya yönelik düşüncelerine etkisine ilişkin öğretmen adayları en az ( $\mathrm{f}=2)$ "Yazma isteğini artırması" kategorisinde görüş bildirmiştir. Bu öğretmen adaylarından (ÖA3) "Yazarken daha keyif almamı sağladı." ve (ÖA7) "Yazma isteğimi artırdı." diyerek öğrendikleri stratejilerin duyuşsal olarak da onları etkilediğini ve yazarken keyif almayı sağlayarak yazma isteğini artırdığını belirtmiştir.

\section{Öğretmen Adaylarının Planlama ve Yazma Stratejilerinin Tartışmacı Anlatıma Dayalı Kompozisyon Yazma Becerisine Etkisine ilişkin Düşüncelerine Yönelik Bulgular}

Yarı yapılandırılmış görüşme formundaki üçüncü soru "Öğrendiğiniz planlama ve yazma stratejileri tartışmacı anlatıma dayalı kompozisyon yazma becerinizi nasıl etkiledi?" sorusudur. Öğretmen adaylarının öğrendikleri planlama ve yazma stratejilerini kullanmanın tartışmacı anlatıma dayalı kompozisyon yazma becerilerine olan etkisine ilişkin görüşleri ile oluşturulan kategoriler ve her bir kategoriye ilişkin frekans ve yüzde değerleri Tablo 4'te verilmiştir. 
Tablo 4.

Öğretmen adaylarının planlama ve yazma stratejilerini kullanmanın tartışmacı anlatıma dayalı plan yapma ve kompozisyon yazma becerisine etkisine ilişkin görüşleri

\begin{tabular}{lrr}
\hline Kategori & f & \multicolumn{2}{c}{$\%$} \\
\hline Bir sav ve karşı sav oluşturmayı sağlama & 14 & 57 \\
Daha planlı ve düzenli yazmayı sağlama & 9 & 37 \\
Tartışmayı öğretme & 1 & 6 \\
\hline
\end{tabular}

Tablo 4'e göre planlama ve yazma stratejilerini kullanmanın tartışmacı anlatıma dayalı plan yapma ve kompozisyon yazma becerisine etkisine ilişkin öğretmen adaylarının görüşleri incelendiğinde, en çok ( $\mathrm{f=14}$ ) "bir sav ve karşı sav oluşturmayı sağlama" ya yönelik görüş bildirildiği görülür. Öğretmen adaylarından (ÖA15) "Tez oluşturmamı ve taraf belirlememi sağladı" ve (ÖA21) "Kendi tezimi üretmemi ve savunmamı sağladı." diyerek tartışmacı anlatımın özelliklerine değinmiştir. (ÖA4) "Bir sav oluşturmamı, onu nasıl savunmam gerektiğini ve daha etkili karşı sav oluşturmamı sağladı." ve (ÖA5) "Tartışmada her iki tarafı da düşünmemi sağladı. Karşı tarafın görüşünü çürütebilmemi kolaylaştırdı." ifadeleriyle öğrendikleri stratejilerin yalnızca bir sav oluştururken değil karşı sav oluştururken de tartışmacı anlatıma dayalı kompozisyon yazmaya etkisi olduğuna değinmiştir.

Öğretmen adayları, öğrendikleri planlama ve yazma stratejilerinin tartışmacı anlatıma dayalı plan yapma ve kompozisyon yazma becerisine etkisine ilişkin ikinci olarak $(\mathrm{f}=9)$ "daha planlı ve düzenli yazmayı sağlama" kategorisinde görüş bildirmiştir. Bu duruma örnek olarak (ÖA16) "Daha sistemli yazmamı sağladı." ve (ÖA9) "Daha düzenli ve planlı yazmamı sağladı." ifadelerini kullanmıştır. (ÖA22) "Doğru adımlarla düşüncelerimi yazmamı sağladı." ve (ÖA11) "Nerede ne yazacağımı bilmemi sağladı." diyerek öğrendikleri bu stratejilerin özellikle kompozisyonu yazarken nerede ne yazacağını öğreterek bir düzen kurmayı sağladığını ve ayrıca düşüncelerini doğru bir biçimde kâğıda aktarabilmede yardımcı olduğunu belirtmiştir. Planlama ve yazma stratejilerini kullanmanın tartışmacı anlatıma dayalı plan yapma ve kompozisyon yazma becerisine etkisine ilişkin öğretmen adaylarının en az $(f=1)$ "tartışmayı öğretme" kategorisinde görüş bildirdikleri görülür. Bu duruma örnek olan öğretmen adayı (ÖA24) "Tartışmayı öğrenmemi sağladı." görüşü ile öğrendiği planlama ve yazma stratejilerinin tartışmacı anlatıma dayalı plan yapma ve kompozisyon yazma becerisine olan etkisini tartışmayı da öğrendiğini belirterek genişletmiştir.

\section{Öğretmen Adaylarının Planlama ve Yazma Stratejilerini Öğrenirken Yaşadıkları Zorluklara ve Bu Stratejileri Sonraki Görevlerde Kullanma Durumlarına Yönelik Bulgular}

Araştırma sonunda, analiz edilen üç görüşme sorusu dışında öğretmen adaylarına görüş bildirmeleri için iki soru daha yöneltilmiştir. Bu sorulardan ilki planlama ve yazma stratejilerini öğrenirken yaşadıkları zorlukların ne olduğuna ilişkindir. Öğretmen adaylarının tamamı $(f=24)$, planlama ve yazma stratejilerini öğrenirken zorluk yaşamadıklarını belirtmiştir. Bu duruma örnek olarak (ÖA3) "Kompozisyon yazarken strateji kullandım ve hiçbir zorluk yaşamadım." ve (ÖA4) "Zorluk yaşamak yerine kolaylık sağladı." ifadeleri verilebilir.

Bu sorulardan ikincisi ise bu stratejileri daha sonraki yazma görevlerinde kullanma durumlarına ilişkindir. Öğretmen adaylarının yine tamamı $(f=24)$, öğrendikleri bu stratejileri daha sonraki yazma görevlerinde daha etkili yazılar yazmak için kullanacaklarına ilişkin görüş bildirmiştir. Öğretmen adaylarından (ÖA21) "Bu stratejiler artık yazacağım her yazıda kendiliğinden zihnimde kullanıma hazır halde olacak." ve (ÖA9) "Bence kullanırım. Kompozisyon yazacağım metin türünü göz ardı etmeden bu stratejileri uygulamaya çalışırım." biçiminde görüş ifade etmiştir. 


\section{Tartışma, Sonuç ve Öneriler}

Öğretmen adaylarının süreç boyunca öğrendikleri planlama ve yazma stratejilerine ilişkin görüşleri incelendiğinde, bu görüşlerin genel olarak üç kategoride "yazma becerisini geliştirmeye yardımcı olma, daha nitelikli yazılar yazmayı sağlama, daha kolay yazmayı sağlama" toplandığı görülür. Öğretmen adayları, öğrendikleri planlama ve yazma stratejilerine ilişkin en çok ( $f=11$ ) "yazma becerisini geliştirmeye yardımcı olma" kategorisinde görüş bildirmiştir. Süreç boyunca öğretmen adaylarına öğretilen planlama stratejileri, yalnızca yazma ürünün niteliği artıracak özellikte değildir. Bu stratejiler süreçsel bir biçimde yapılandırıldığından ürünün niteliğinin artırmasının yanında yazma sürecini destekleyerek yazma becerisini de geliştirmeye yardımcı olur. Öğretmen adaylarının, süreç boyunca öğrendikleri planlama ve yazma stratejilerine ilişkin en çok yazma becerisini geliştirmeye yardımcı olmasına yönelik görüş bildirirek araştırmada kullanılan planlama ve yazma stratejilerinin tüm yazma sürecine olan etkisinin alanyazına bir başka kanıtını sunar. Alanyazında Müldür (2017), Çağlayan Dilber (2014) ve Uygun (2012)'un çalışmalarında da katılımcılar, süreç boyunca öğrendikleri stratejilere ilişkin yazma becerilerini geliştirdiğini ve deneysel uygulama sonrasında yazdıkları metinlerin değiştiğini ve geliştiğine yönelik görüş bildirmiştir. Ayrıca benzer biçimde yapılan uluslararası çalışmalarda da özdüzenlemeli strateji geliştirme modeliyle yapılandırılan strateji öğretiminin öğrencilerin yazmaya yönelik bilgi ve becerilerine katkı sağladığı görüşü yer alır (Graham vd, 2005; De La Paz ve Graham, 2002).

Öğretmen adayları, ikinci olarak $(\mathrm{f}=8)$ "daha nitelikli yazılar yazmayı sağlama" kategorisinde görüş bildirmiştir. Stratejiler, daha iyi yazmayı engelleyebilecek çeşitli sorunları çözümü için işe koşulan bilişsel işlemlerdir ve bu işlemler yazma sürecinde ortaya çıkan ürünün niteliği artmasına yardımcı olur. Öğretmen adaylarının stratejileri işe koşarak "daha nitelikli yazılar" yazdıklarını belirtmeleri yazma stratejilerini kullanmanın ortaya çıkan ürünün niteliğinin artmasını sağladığına yönelik bir göstergedir. Benzer biçimde Uygun (2012)'un çalışmasında özdüzenlemeli strateji geliştirme modeliyle öykü yazan öğrenciler, özdüzenlemeli strateji geliştirme modeliyle daha nitelikli öyküler yazdıklarına ilişkin görüş bildirmiştir. Çağlayan Dilber (2014) çalışmasında ise katılımcılar özdüzenlemeli strateji geliştirme modeliyle gereçkeleştirilen öğretimle oluşturdukları metin yapısında değişim sağladığına ilişkin görüş bildirerek daha nitelikli ürünler ortaya çıkardıklarına değinmiştir. Elde edilen bu sonuç yapılan uluslararası araştırmalarla da tutarlııı göstermektedir (Graham, Harris ve Mason, 2005; Zumbrunn, 2010; Tracy, Reid ve Graham, 2009; Zumbrunn ve Bruning, 2012). Buradan hareketle özdüzenlemeli strateji geliştirme modeliyle gerçekleştirilen planlama ve yazma stratejileri öğretimi ile daha nitelikli ve tutarlı metinler üretilebileceği söylenebilir.

Planlama ve yazma stratejilerine yönelik son olarak $(f=4)$ "daha kolay yazmayı sağlama" kategorisinde görüş bildirildiği belirlenmiştir. Yazma süreci, bireyin yazma konusunu düşünmeye başladığı andan yazma sürecini tamamlayana kadar iç içe geçmiş bir dizi karmaşık işlemden oluşur. Bu işlemler sırasında planlama, metin üretme ve gözden geçirme stratejilerini daha etkili bir biçimde uygulayanların, süreç sonunda kompozisyon yazmanın eskiden zannettikleri kadar zor olmadığını dile getirdikleri bilinmektedir (Bai, 2015). Öğretmen adaylarının da benzer biçimde bu işlemleri yerine getirirken stratejileri kullanmış olmasının süreci kolaylaştırdığı söylenebilir. Benzer biçimde Müldür (2017)'ün çalışmasında katılımcılar, özdüzenlemeli strateji geliştirme modeliyle yaptıkları etkinliklerin daha kolay yazmayı sağladığını belirtmiştir. Uygun (2012)'un çalışmasında ise öğrenciler, özdüzenlemeli strateji geliştirme modeliyle yaptıkları etkinlikleri beğenme nedenleri içinde en çok yazı yazmayı kolaylaştırma özelliğini vurgulamıştır.

Öğretmen adaylarının planlama ve yazma stratejilerini kullanmanın yazmaya yönelik düşüncelerine etkisine ilişkin görüşleri incelendiğinde, üç kategori, yazmaya yardımcı olma ve yazmayı kolaylaştırma ( $f=11)$-düzenli ve sistemli yazmayı sağlama ( $f=7)$-yazmaya yönelik kaygıyı azaltması $(f=4)$ - yazma isteğini artırması $(f=2)$ oluşmuştur. Bu kategoriler içinde en çok ( $f=11)$ "yazmaya yardımcı 
olma ve yazmayı kolaylaştırma"ya yönelik görüş bildirildiği görülür. Stratejiler, verilen görevleri yerine getirmede kolaylaştırıcı bir rol üstlenir. Yazma sürecinde kullanılan stratejiler de yazma sürecine yardımcı olarak yazmayı kolaylaştırır. İlk okuma yazmadan yüksek öğrenime kadar süregelen akademik eğitimlerinde öğrencilerin yazmaya ilişkin pek çok sorun yaşadıkları bilinir. Oysa bu çalışmanın sonunda öğretmen adayları, planlama ve yazma stratejilerini kullanmanın yazmaya yönelik olumlu etkisine ilişkin görüş bildirerek kompozisyon yazmalarını kolaylaştırdığını belirtmişlerdir. Bu durum doğrultusunda, öğretmen adaylarının kullandıkları stratejilerin de yazma sırasında yaşadıkları birtakım zorlukların ortadan kaldırmaya yardımcı olarak kompozisyon yazmayı kolaylaştırdığı söylenebilir. Alanyazında yer alan çalışmalarda da benzer biçimde özdüzenlemeli strateji geliştirme modelinin yazmaya yardımcı olarak yazmayı kolaylaştırdığına ilişkin katılımcı görüşleri yer alır (Müldür, 2017; Çağlayan Dilber, 2014; Uygun, 2012).

Planlama ve yazma stratejilerinin yazmaya yönelik düşüncelerine etkisine ilişkin ikinci olarak $(\mathrm{f}=7)$ "Düzenli ve sistemli yazmayı sağlama" kategorisinde görüş bildirilmiştir. Yazma öğretiminde strateji kullanmadaki amaç, stratejilerin yönlendirici yapısıyla yazmayı düzenleme ve amaca uygun biçime getirmektir. Bu amaca uygunluk da oluşturulacak olan yazının düzenli ve sistemli kurgulanmasını sağlamaya yardımcı olur. Yazılı bir anlatımın ilk kuralı, aktarılacak duygu ve düşünceleri yazma amacına uygun olarak planlamak ve bu planı düzenli bir biçimde metne aktarmaktır. Hedef okuyucu kitlesi göz ününde bulundurularak yazılacak olan kompozisyonun ana düşüncesi ve ana düşünceyle ilintili yardımcı düşünceleri yazmadan önce planlanmalı ve yazma sürecinde yeniden düzenlenerek yazıya aktarılmalıdır. Araştırmada kullanılan planlama ve yazma stratejilerinde düşünceleri düzenleme ve geliştirme basamaklarıyla öğretmen adaylarının daha planlı ve düzenli yazmalarını sağlamak amaçlandığından, planlama stratejisinde "düşüncelerini düzenleme" ve yazma stratejisinde "düşünceleri geliştirme" basamağı bulunur. Bu basamaklarda, düşünceleri en güçlüden en zayıfa veya en önemliden en az önemli olana doğru doğru sıralama ile bu düşünceler arasındaki düzeni sağlamaya dayalı bir yönerge ve konuya ilişkin tez cümlesini geliştirme ile yazının ana hatlarını belirleyecek konu cümleleri hazırlamaya ilişkin bir diğer yönerge yer alır. Öğretmen adaylarının, planlama ve yazma stratejilerini kullanmanın tartışmacı anlatıma dayalı plan yapma ve kompozisyon yazma becerisine etkisine yönelik "daha planlı ve düzenli yazmayı sağlaması" na ilişkin görüş bildirmeleri araştırmada kullanılan stratejilerin ilgili basamaklarının katkısı ile ilişkili olduğu söylenebilir. Bu durum, öğretmen adaylarının öğrendikleri stratejilerin kompozisyon yazmalarına olan katkısının farkına vardıklarının bir göstergesi olarak yorumlanabilir.

Planlama ve yazma stratejilerinin yazmaya yönelik düşüncelerine etkisine ilişkin üçüncü olarak $(\mathrm{f}=4)$ "Yazmaya yönelik kaygıyı azaltması”na yönelik görüş bildirilmiştir. Bu görüş öğretmen adaylarının yazma stratejilerini kullanarak yazma sürecinde karşılaştıklarını zorlukları yalnızca bilişsel değil duyuşsal olarak da çözebileceklerine yönelik bir farkındalığın göstergesi olarak yorumlanabilir. Yazmaya yönelik kaygı, yazma başarısını etkileyen bir unsurdur. Yazma kaygısı taşıyan bireyler, yazma görevini yerine getirmekte zorlanır ve yazma görevi ile baş başa kalmaktan endişe duyar. Yazma stratejileri, yazma sırasında yaşanabilecek duyuşsal zorluklarla başa çıkabilmeyi sağladığı için strateji kullanımı yazma kaygısını azaltıcı bir görev üstlenmesi de beklenmektedir. modelde yer alan aşamalardan olan "stratejiye model olma" aşaması ön plana çıkmaktadır. Öğretim sürecinde araştımacı, yalnızca planlama ve yazma stratejilerini öğretmemiş aynı zamanda sesli düşünme protokollerini (think aloud protocols) kullanarak strateji kullanımına model de olmuştur.

Tompkins (2008), yazma stratejileri kullanımına model olurken yazma süreci içinde kullanılan sesli düşünme protokollerinin öğreticinin yazma stratejilerine ilişkin kendi düşünce ve stratejilerini örnek vermesini sağladığı, normalde yazma süreci içinde gözle görülemeyen planlama, taslak hazırlama, düzeltme gibi bilişsel süreçleri gözle görünür kılması bakımından önem taşıdığını belirtir. Bu nedenle, öğreticinin stratejiye model olması ile öğretmen adayıların süreç boyunca kaygılanmalarını gerektirecek noktaları önceden görmelerini ve olumsuz duygularla nasıl baş edeceklerini; göstermeyi 
sağladığı için stratejinin yazma kaygısını da azaltarak amacına ulaştığı söylenebilir. Akıncılar (2010) çalışmasında katılımcılar özdüzenlemeli strateji geliştirme modeliyle yapılandıılan strateji öğretimi ile yazma konusunda kendilerine güvenlerinin artarak kaygılarının azaldıklarını belirterek araştırmanın bu bulgusunu desteklemiştir.

Planlama ve yazma stratejilerinin yazmaya yönelik düşüncelerine etkisine ilişkin öğretmen adayları en az ( $\mathrm{f}=2$ ) "Yazma isteğini artırması" kategorisinde görüş bildirmiştir. Bu durum, yazmanın bilişsel olduğu kadar duyuşsal bir etkinlik olduğununun bir başka göstergesidir. Alanyazında, yazı yazmak istemeyişin yazma becerisinin gelişiminin önündeki en büyük engel olduğu (Kurudayıoğlu ve Karadağ, 2010), yazma becerisinin geliştirlmesinde öğrencilerin yazmaya isteklendirilmesinin oldukça önemli olduğu (Demir, 2012) ve yazma performanslarını doğrudan etkileyen unsurların başında motivasyonun geldiği (Lam ve Law, 2007) sıklıkla belirtilir. Özdüzenlemeli strateji geliştirme modeli, öğrencilerin yazmaya yönelik duyuşsal gelişimlerini de olumlu etkilenmesini sağlar (Graham ve Harris, 2005; Zumbrunn, 2010). Öğretmen adayları da benzer biçimde planlama ve yazma stratejilerini yazma çalışmalarında kullanarak yazmaya yönelik bir motivasyon sağladıklarını belirtmişlerdir. Uygun (2012) çalışmasında, ÖDSGM ile yapılan öğretim sonrası katılımcıların yazma isteğinin artı̆̆ına yönelik görüşler bildirdiğini ve bu nedenle modelin doğru işletilerek olumlu tutumu geliştirdiğini belirtir. Müldür (2017), ÖDSGM katılımcı görüşleri ile motivasyon teması oluşturmuş ve katılımcıların yazmaya ilişkin yüksek motivasyon ile olumlu tutum içeren görüşlerini örneklemiştir. Benzer biçimde, Çağlayan Dilber (2014)'in çalışmasında da özdüzenlemeli strateji geliştirme modeliyle yapılandırılan tartışmacı anlatıma dayalı metin üretimi stratejilerine yönelik öğrencilerin çok daha istekli yazmaya başladıklarını vurgular. Alanyazındaki çalışmalar, araştırmanın bu bulgusunu desteklemektedir.

Planlama ve yazma stratejilerini kullanmanın tartışmacı anlatıma dayalı plan yapma ve kompozisyon yazma becerisine etkisine ilişkin öğretmen adaylarının görüşleri incelendiğinde, bu görüşlerin genel olarak üç temada toplandığı, bir sav ve karşı sav oluşturmayı sağlaması ( $f=14)$-daha planlı ve düzenli yazmayı sağlaması ( $f=9)$-tartışmayı öğretmesi $(f=1)$, görülmektedir. Bu kategori içinde en çok ( $\mathrm{f}=14$ ) "bir sav ve karşı sav oluşturmayı sağlama" kategorisinde görüş bildirilmiştir. Nitelikli bir metin üretimi için metin yapısına ilişkin bilgi edinmek ve metin yapısına uygun süreçleri izlemek oldukça önemlidir. Bir metni oluştururken metin türüne yönelik bellekte var alan şemadan yola çıkılarak yeni düşünceler oluşturulur ve oluşturulan bu yeni düşüncelerin düzenli biçimde sunulması ancak metin türü bilgisinin bellekte doğru yapılandırılmış olması ile gerçekleşir. Kısacası, bir metin yapısını oluşturan en önemli unsur o metin yapısını oluşturan temel metin elementleridir ve bireyin bir yazma görevini gerçekleştirmeden önce ortaya koyacağı metin türüne ilişkin yeterli bir bilgi edinmiş olması oluşturulacak olan metnin niteliği açısından oldukça önemlidir. Tartışmacı metin yapısı temel olarak "bir sav ve karşı sav"dan oluşmaktadır. Araştırmada, öğretim sürecinde kullanılan stratejiler tartışmacı metin yapısı öğretimine uygun olarak yapılandırılmış ve öğretim sürecinde metin yapısına ilişkin bilgiler verilerek öğretmen adaylarının yeterliliği sağlanmaya çalışılmıştır. Burada öğretmen adaylarııın planlama ve yazma stratejilerini kullanmanın tartışmacı anlatıma dayalı plan yapma ve kompozisyon yazma becerisine etkisine ilişkin en çok "bir sav ve karşı sav oluşturmayı sağlaması"na yönelik görüş bildirmesi tartışmacı metin yapısını oluşturan temel elementleri kavramış olduklarının bir göstergesi olarak yorumlanabilir. Benzer biçimde Çağlayan Dilber (2014)'in tartışmacı anlatıma dayalı metin üretimi stratejilerine yönelik gerçekleştirdiği çalışmasında katılımcıların süreç sonunda daha etkileyici ve ikna edici yazdıklarına yönelik görüş bildirdiklerini belirtir. Elde edilen bu bulgular, özdüzenlemeli strateji geliştirme modeliyle yapılandırılan strateji öğretimi çalışmalarının öğrencilerin tartışmacı metin elementlerini oluşturma düzeylerinde etkili olduğunun kanıtı biçimindedir.

Öğretmen adayları, öğrendikleri planlama ve yazma stratejilerinin tartışmacı anlatıma dayalı plan yapma ve kompozisyon yazma becerisine etkisine ilişkin ikinci olarak $(\mathrm{f}=9)$ "daha planlı ve düzenli yazmayı sağlama" kategorisinde görüş bildirmişlerdir. Ayrıca, özdüzenlemeli strateji geliştirme modelinde sürecin önemli bir parçası, yol gösterici öğretici olmadan da öğrencilerin bağımsız olarak 
görevi yerine getirmesi ve düşüncelerini düzenlerken amaç belirleme ve kendi kendini izleme gibi özdüzenleme becerilerini etkin kullanmalarını sağlamaktır. Özdüzenlemeli strateji geliştirme modelinin kullanıldığı benzer çalışmalarda öğrencilerin planlama ve gözden geçirmeye daha fazla zaman ayırdığı (Asaro-Saddler ve Bak, 2015) ve böylece daha planlı ve düzenli yazdıkları belirtilmektedir. Alanyazında benzer biçimde Ögülmüş (2018) ve Çağlayan Dilber (2014) çalışmalarında katılımcıların uygulaması yapılan stratejilerin katılımcılar tarafından öğrenildiğinin bir göstergesi olarak katılımcıların görüşlerinde planlama basamaklarından ve plan yaptıklarından söz etmeleri, daha planlı ve düzenli bir biçimde yazdıklarını belirtmelerini araştırmanın bu bulgusunu destekler niteliktedir. Planlama ve yazma stratejilerini kullanmanın tartışmacı anlatıma dayalı plan yapma ve kompozisyon yazma becerisine etkisine ilişkin öğretmen adaylarının en az $(f=1)$ "tartışmayı öğretme" kategorisinde görüş bildirdikleri görülmüştür. Tartışma, birbirine karşıt düşünceleri karşılıklı savunmadır. Bu savunuyu yaparken eleştirel ve yaratıı düşünme, farklı bakış açılarını değerlendirme ile sorun çözme becerilerini kullanmak gerekmektedir. Tartışmacı metinler bu beceriler aracılığıyla düşüncelerin yazıya dökülerek ifade edilmesi sağlar. Araştımada öğretimi gerçekleştirilen tartışmacı metin yapısının dolaylı olarak tartışmayı da öğretmesi öğretmen adaylarının bu beceri alanlarında da gelişimini sağlaması açısından önemlidir.

Araştırma sonunda, analiz edilen üç görüşme sorusu dışında öğretmen adaylarına görüş bildirmeleri için iki soru daha yöneltilmiştir. Bu sorulardan ilki planlama ve yazma stratejilerini öğrenirken yaşadıkları zorlukların ne olduğuna ilişkin; ikincisi ise bu stratejileri daha sonraki yazma görevlerinde kullanma durumlarına ilişkindir. Öğretmen adaylarının tamamı $(f=24)$, planlama ve yazma stratejilerini öğrenirken zorluk yaşamadıklarına ve öğrendikleri bu stratejileri daha sonraki yazma görevlerinde daha etkili yazılar yazmak için kullanacaklarına ilişkin görüş bildirmişlerdir. Planlama ve yazma stratejilerinin yazma becerisinin gelişimine olan etkileri alanyazında pek çok çalışmada yer almaktadır. Araştırmada yer alan öğretmen adaylarının yazma eğitiminin stratejik olması gerektiğinin farkına vararak bunu kolayca çalışmalarına yansıtmalarına ve öğrendikleri bu stratejileri daha sonraki yazma görevlerinde daha etkili yazılar yazmak için kullanacaklarına ilişkin görüş bildirmeleri gelecekte yetiştirecekleri öğrencilere stratejik bir yazma öğretimi yapacaklarının sağlam bir ifadesidir. Akıncılar (2010) ve Öğülmüş (2018) çalışmalarında da katılımcılar, stratejileri kullanırken zorluk yaşamadıklarını ve bu stratejiler ile sonraki yazılarda kolaylıkla yazı yazılabileceğini belirterek araştıma sonucuyla benzer bir sonuç elde etmişlerdir.

Öğretmen adaylarının görüşleri bir bütün olarak değerlendirildiğinde araştırmada özdüzenlemeli strateji geliştirme modeliyle yapılandırılan planlama ve yazma stratejileri öğretiminin yazma becerisini geliştirmeye yardımcı olarak yazma sürecini kolaylaştırma, planlı ve düzenli yazmayı sağlama, nitelikli yazılar yazmayı sağlama, yazmaya yönelik kaygıyı azaltma ve yazma isteğini artırma gibi açılardan yazma becerilerine doğrudan katkısının olduğu görülmektedir. Bu öğretimin ayrıca öğretmen adaylarının yazmaya yönelik kaygıyı azaltma ve yazma isteğini artırma gibi duyuşsal katkısının olduğu ve öğrendikleri stratejileri farklı görevlere zorlanmadan aktarabilme yönüyle de kişisel gelişimlerine yönelik katkısının olduğu söylenebilir. Özelde metin türü bağlamında değerlendirildiğinde, öğretimin metin türü öğretimini gerçekleştirdiği için akademik olarak da öğretmen adaylarına katkısının olacağı açıktır. Bir öğretmen adayının öğrencilerine stratejik bir yazma öğretimi gerçekleştirmesi ve yazma stratejilerini kavratması için öncelikle kendisinin yazmaya ilişkin stratejik bir görüş geliştirmiş olması gerekmektedir. Bu bakımdan araştırmada yer alan Türkçe öğretmeni adaylarının yazma stratejilerine ilişkin geliştirmiş oldukları bu farkındalık alanyazına doğrudan etki edecek bir sonuç oluşturmuştur.

Araştırma sonucunda, Türkçe öğretmeni adaylarının gelecek yazma görevlerinde öğrendikleri stratejileri öğrencilerine aktaracakları ve bu stratejilerin karşılıklı olarak yazma gelişimlerine katkı sunacağı belirlenmiştir. Buradan hareketle, Türkçe öğretmenliği lisans programında yazma eğitimi derslerinde yazma stratejilerinin öğretimde etkin kullanımının sağlanması ve strateji öğretiminin önemi 
konusunda Türkçe öğretmeni adaylarınının farkındalık ve yeterlik düzeyi yükseltilmesi için gerekli çalışmaların yapılması önerilebilir. Ayrıca görev yapan Türkçe öğretmenlerinin de çeşitli hizmetiçi eğitimlerle benzer biçimde stratejileri öğrenme ve uygulama konusunda farkındalık ve yeterliklerinin artırılması öğretmenlerin mesleki gelişimlerine katkı sağlamak açısından önem taşımaktadır. Sonuç olarak, gelecekte eğitsel içerik tasarlayıcısı ve uygulayıcısı olacak olan, dersinin hedef kazanamına yönelik uygun stratejileri belirleyip uygulamakla sorumlu olan öğretmenlere ve özelde Türkçe öğretmeni adayları ile Türkçe öğretmenlerine strateji eğitimi vermek ve onların stratejilere yönelik görüşlerini belirlemek oldukça önemlidir. 


\section{Kaynakça}

Akıncılar, V. (2010). Özdüzenleme strateji gelişimi (SRSD) öğretim modeli ile verilen "PLEASE" strateji eğitiminin Ingilizce'yi yabancı dil olarak öğrenen beşinci sınıf öğrencilerinin betimleyici yazıları üstüne etkisi: Planlama üstüne bir strateji eğitimi (Yayımlanmamış yüksek lisans tezi). ODTÜ, Ankara. YÖK Ulusal Tez Merkezi veri tabanından erişildi.

Altunışık, R., Coşkun, R., Bayraktaroğlu, S. ve Yıldırım, E. (2012). Sosyal bilimlerde araştırma yöntemleri (SPSS uygulamalı). Ankara: Seçkin Yayıncılık.

Asaro-Saddler, K. ve Bak, N. (2015). Persuasive writing and self-regulation training for writers with autism spectrum disorders. Journal of special education, 48 (2), 92-105. doi: http://dx.doi.org/ 10.1177/0022466912474101.

Bai, B. (2015). The effects of strategy-based writing instruction in Singapore primary schools. System, 53, 96-106. doi: https://doi.org/10.1016/j.system.2015.05.009.

Balsamo, A. M. (2019). Effects of self-regulated strategy development on the writing performance and sense of self-efficacy of postsecondary english language learners. (Master Thesis). ProQuest Dissertations ve Theses Global veri tabanından erişildi.

Berry, A. B. ve Mason, L. H. (2012). The effects of self-regulated strategy development on the writing of expository essays for adults with written expression difficulties: Preparing for the GED. Remedial and Special Education, 33 (2), 124-136. doi: http://dx.doi.org/ 10.1177/0741932510375469.

Büyüköztürk, Ş., Çakmak, E. K., Akgün, Ö. E., Karadeniz, Ş. ve Demirel, F. (2017). Bilimsel araştırma yöntemleri. Ankara: Pegem Akademi.

Can, B. (2016). Öz düzenlemeli strateji geliştirmeye dayalı öğretim modelinin öykü yazma becerilerini geliştirmeye etkisi (Yayımlanmamış doktora tezi). Gazi Üniversitesi, Ankara. YÖK Ulusal Tez Merkezi veri tabanından erişildi.

Creswell, J. W. (2013). Araştırma deseni: nitel, nicel karma yöntem yaklaşımları. (Çev. Ed. S.B. Demir). Ankara: Eğiten Kitap.

Çağlayan Dilber, N. (2014). Öz düzenlemeli strateji gelişimi öğretim modelinin ortaokul öğrencilerinin ürettikleri tartışmacı metinlere etkisi. (Yayımlanmamış doktora tezi). Ankara Üniversitesi, Ankara. YÖK Ulusal Tez Merkezi veri tabanından erişildi.

De La Paz, S. ve Graham, S. (1997a). Strategy instruction in planning: Effects on the writing performance and behavior of students with learning difficulties. Exceptional Children, 63 (2), 167-181. Erişim adresi: https://asu.pure.elsevier.com/en/publications/strategy-instruction-in-planning-effects-on-the-writingperforman-2. 07.02.2020 tarihinde erişildi.

De La Paz, S. ve Graham, S. (1997b). Effects of dictation and advanced planning instruction on the composing of students with writing and learning problems. Journal of Educational Psychology, 89, 203-222. doi:https://doi.org/10.1037/0022-0663.89.2.203.

De La Paz, S. ve Graham, S. (2002). Explicitly teaching strategies, skills, and knowledge: Writing instruction in middle school classrooms. Journal of Educational Psychology, 94(4), 687698. https://doi.org/10.1037/0022-0663.94.4.687.

Demir, T. (2013). Türkçe eğitiminde yaratıcı yazma becerisini geliştirme ve küçürek öykü. Mustafa Kemal Üniversitesi Sosyal Bilimler Enstitüsü Dergisi, $9 \quad$ (19), $343-357$. https://dergipark.org.tr/tr/pub/mkusbed/issue/19551/208390 adresinden erişildi.

Demirel, Ö. (1999). Türkçe ögrretimi. Ankara: Pegem Yayıncılık.

Graham, S. (2008). Effective writing instruction for all students. Renaissance Learning Vanderbilt University Pub. Erişim adresi: http://dsrpresources.pbworks.com/w/file/fetch/70407753/R004250923GJCF33.pdf. 10.02.2020 tarihinde erişildi.

Graham, S. ve Harris, K. R. (1999). Assessment and intervention in overcoming writing difficulties: An illustration from the self-regulated strategy development model. Language, Speech, and Hearing Services in Schools, 30 (3), 255-264. doi: https://doi.org/10.1044/0161 1461.3003.255.

Graham, S. ve Perin, D. (2007). A meta-analysis of writing instruction for adolescent students. Journal of Educational Psychology, 99 (3), 445-476. doi: https://doi.org/10.1037/0022-0663.99.3.445

Graham, S., Harris, K. R. ve Mason, L. (2005). Improving the writing performance, knowledge, and self-efficacy of struggling young writers: The effects of selfregulated strategy development. Contemporary Educational Psychology, 30 (2), 207-241. doi:https://doi.org/10.1016/j.cedpsych.2004.08.001.

Graham, S., Harris, K.R. ve Santangelo, T. (2015). Research-based writing practices and the common core: metaanalysis and meta-synthesis. The Elementary School Journal, 115 (4), 498-522. http://www.jstor.org/stable/10.1086/681964. adresinden erişildi. 
Gültekin, D. (2016). Yazma öz-düzenleme stratejilerinin geliştirilmesi: Ingilizce'yi yabancı dil olarak öğrenen Türk bir öğrenci ile yapılan durum çalışması (Yayımlanmamış yüksek lisans tezi). Marmara Üniversitesi, İstanbul. YÖK Ulusal Tez Merkezi veri tabanından erişildi.

Güneş, F. (2013). Türkçe öğretimi: yaklaşım ve modeller. Ankara: Pegem Akademi.

Harris, K. R., Graham, S. ve Mason, L. H. (2006). Improving the writing, knowledge, and motivation of struggling young writers: Effects of self-regulated strategy development with and without peer support. American Educational Research Journal, 43 (2), 295-340. doi: https://doi.org/10.3102/00028312043002295.

Kurudayıoğlu, M. ve Karadağ, Ö. (2010). İlköğretim öğrencilerinin yazılı anlatımlarının konu seçimleri açısından incelenmesi. Mustafa Kemal Üniversitesi Sosyal Bilimler Enstitüsü Dergisi, 7(13), 192-207. https://dergipark.org.tr/tr/pub/tubar/issue/16968/177243 adresinden erişildi.

Lam, S.F. ve Law, Y.K. (2007). The roles of instructional practices and motivation in writing performance. The Journal of Experimental Education, $75 \quad(2), \quad 145-164 . \quad$ Erişim adresi: https://hub.hku.hk/bitstream/10722/57182/1/134623.pdf?accept=1. 24.02.2020 tarihinde erişildi.

Mason, L.H., Harris, K.R. ve Graham, S. (2011) Self-regulated strategy development for students with writing difficulties. Theory into Practice, 50 (1), 20-27. doi: https://doi.org 10.1080/00405841.2011.534922.

Miles, M. B. ve Huberman, A. M. (1994). Qualitative data analysis: An expanded sourcebook. Sage Publications, Inc.

Müldür, M. (2017). Öz düzenlemeye dayali yazma eğitiminin ortaokul öğrencilerinin bilgilendirici metin yazma becerisine, yazmaya yönelik öz düzenleme becerisine ve yazma öz yeterlik algısına etkisi (Yayımlanmamış doktora tezi). Gazi Üniversitesi, Ankara. YÖK Ulusal Tez Merkezi veri tabanından erişildi.

Pressley, M., Rankin, J. ve Yokoi, L. (1996). A survey of instructional practices of primary grade teachers nominated as effective in promoting literacy. Elementary School Journal, 96, 363-384. doi: https://doi.org/10.1086/461834.

Roberts, P. ve Priest, H. (2006). Reliability and validity in research. Nursing Standard, 2, 41-45. doi: http://dx.doi.org/10.7748/ns.20.44.41.s56.

Rogers, L. A. (2010). Effect of self-regulated strategy development story-writing instruction: Adult school volunteers in action. (Yayımlanmamış doktora tezi). ProQuest Dissertations ve Theses Global veri tabanından erişildi.

Rogers, L. A. ve Graham, S. (2008). A meta-analysis of single subject design writing intervention research. Journal of educational psychology, 100, 879-906. doi: https://doi.org/10.1037/0022-0663.100.4.879.

Saddler, B., Moran, S., Graham, S. ve Harris, K. R. (2004). Preventing writing difficulties: The effects of planning strategy instruction on the writing performance of struggling writers. Exceptionality, 12 (1), 3-17. doi:https://doi.org/10.1207/s15327035ex1201 2.

Tompkins, G. E. (2008). Teaching writing balancing process and product. New Jersey: Pearson Education.

Tracy, B., Reid, R. ve Graham, S. (2009). Teaching young students strategies for planning and drafting stories: The impact of self-regulated strategy development. The journal of Educational Research, 102 (5), 323-331. doi: https://doi.org/ 10.3200/JOER.102.5.323-332.

Uygun, M. (2012). Öz düzenleme stratejisi gelişimi öğretiminin yazılı anlatıma, yazmaya yönelik öz düzenleme becerisine, kalıcılığa ve tutuma etkisi (Yayımlanmamış doktora tezi). Hacettepe Üniversitesi, Ankara. YÖK Ulusal Tez Merkezi veri tabanından erişildi.

Yıldırım, A. ve Şimşek, H. (2013). Sosyal bilimlerde nitel araştırma yöntemleri. Ankara: Seçkin Yayıncılık.

Zimmerman, B. J. ve Reisemberg. (1997). Becoming a self-regulated writer: A social cognitive perspective. Contemporary educational psychology, 22 (1), 73-101. doi: https://doi.org/10.1006/ceps.1997.0919.

Zumbrunn, S. K. (2010). Nurturing young students' writing knowledge, self-regulation, attitudes, and self-efficacy: The effects of self-regulated strategy development. ProQuest Dissertations \& Theses Global veri tabanından erişildi.

Zumbrunn, S. ve Bruning, R. (2013). Improving the writing and knowledge of emergent writers: the effects of selfregulated strategy development. Reading and Writing, 26, 91-110. doi: https://doi.org/10.1007/s11145-012-9384-5 